\title{
Resistance transferance of Amorimia septentrionalis poisoning in goats by ruminal transferance fluid from goats with induced resistance by the inoculation of sodium monofluoroacetate-degrading bacteria
}

\author{
Transferência da resistência à intoxicação por Amorimia septentrionalis em caprinos mediante \\ transfaunação de conteúdo ruminal proveniente de caprinos com resistência induzida \\ pela inoculação de bactérias degradadoras de monofluoroacetato de sódio \\ Layze Cilmara Alves da Silva ${ }^{I^{*}}$ Danielle Aluska do Nascimento Pessoa ${ }^{\mathrm{I}}$ \\ José Radmácyo Gomes Lopes ${ }^{I}$ Leomyr Sângelo Alves da Silva ${ }^{I I}$ Laio Gomes de Albuquerque ${ }^{\mathrm{I}}$

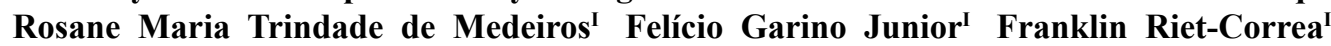

\section{ABSTRACT}

\begin{abstract}
Amorimia septentrionalis is a sodiummonofluoroacetate (MFA) - containing plant that causes sudden death in ruminants. The aim of this study was to determine whether the resistance to $A$. septentrionalis poisoning in goats conferred by the intra-ruminal inoculation with the MFA-degrading bacteria Ancylobacter dichloromethanicus and Pigmentiphaga kullae can be transferred to susceptible goats by the transfaunation of rumen content. Two groups of 8 goats and 2 goats resistant to $A$. septentrionalis poisoning were used. Goats in Group 1 received four daily doses of $160 \mathrm{ml}$ of rumen content from resistant goats and subsequently ingested 8 daily doses of $5 \mathrm{~g} \mathrm{~kg}^{-1}$ of A. septentrionalis. Goats from Group 2 (control) received only the plant. In Group 1, only 2 goats showed mild tachycardia and mild jugular vein engorgement on the $4^{\text {th }}$ and $5^{\text {th }}$ day, but they subsequently returned to normal, even with the continuation of plant administration. All control goats showed severe signs of intoxication and the plant administration was suspended between the $3^{\text {rd }}$ and $7^{\text {th }}$ day. So, the transfer of ruminal fluid from goats previously inoculated with MFA-degrading bacteria induces resistance to poisoning by $A$. septentrionalis in susceptible goats.
\end{abstract}

Key words: Ancylobacter dichloromethanicus, Pigmentiphaga kullae, sudden death, toxic plants.

RESUMO

Amorimia septentrionalis é uma planta que contém monofluoracetato de sódio (MFA) e causa morte súbita em ruminantes. $O$ objetivo deste trabalho foi determinar se a resistência à intoxicação conferida por A. septentrionalis em caprinos inoculados com as bactérias degradadoras de MFA, Ancylobacter dichloromethanicus e Pigmentiphaga kullae, pode ser transferida, por transfaunação ruminal, para outros caprinos suscetiveis. Para tanto, foram utilizados dois caprinos previamente inoculados com bactérias degradadoras de MFA e dois grupos de oito caprinos para o experimento de transfaunação, denominados Grupo 1 e Grupo 2. Os caprinos do Grupo 1 receberam 4 doses diárias de $160 \mathrm{ml}$ de conteúdo ruminal dos caprinos resistentes e, posteriormente, ingeriram 8 doses diárias de $5 \mathrm{~g} \mathrm{kg-1} \mathrm{da} \mathrm{planta.}$ Os caprinos do Grupo 2 (controle) receberam apenas a planta. Dos caprinos do Grupo 1, apenas 2 animais apresentaram discreta taquicardia e leve ingurgitamento da veia jugular no $4^{\circ}$ e $5^{\circ}$ dia do experimento, no entanto, estes voltaram ao normal, mesmo com a continuação da administração da planta. Todos os animais do grupo controle apresentaram sinais graves de intoxicação e a administração da planta foi suspensa entre e o 3o e o 7o dia. Concluise que a transfaunação de líquido ruminal de caprinos previamente inoculados com bactérias degradadoras de MFA induz resistência à intoxicação por A. septentrionalis em outros caprinos susceptiveis.

Palavras-chave: Ancylobacter dichloromethanicus, Pigmentiphaga kullae, morte súbita, plantas tóxicas.

\section{INTRODUCTION}

Amorimia septentrionalis, more commonly known as "tingui” (MAMEDE, 2010), is part of an important group of toxic plants in Brazil that contain sodium monofluoroacetate (MFA) (LEE et al., 2012) and cause sudden death in cattle (TOKARNIA et al. 1994, MEDEIROS et al. 2002), goats (OLIVEIRA et al., 1978) and sheep (SILVA et al., 2008). This group of plants, including Amorimia spp. Palicourea spp. and Arrabidaea spp., are responsible for causing approximately 500.000 cattle deaths per year in Brazil (PESSOA et al., 2013).

Alternatives to control these poisonings have been studied, including the induction of resistance to MFA using bacteria that produce dehalogenases

\footnotetext{
IHospital Veterinário, Centro de Saúde e Tecnologia Rural, Universidade Federal de Campina Grande (UFCG), Avenida Universitária, s/n, Bairro Santa Cecília, 58708-110, Patos, PB, Brasil. E-mail: layze.cilmara@hotmail.com. *Corresponding author.

IUniversidade Estadual da Paraíba (UEPB), Campina Grande, PB, Brasil.
} 
and inactivate this toxic compound (PESSOA et al., 2013). CAMBOIM et al. (2012a) isolated two aerobic MFA-degrading bacteria, Ancylobacter dichloromethanicus and Pigmentiphaga kullae, from the rumen content of goats and recent studies demonstrated an increased resistance to poisoning by MFA-containing plants in goats inoculated with these bacteria (PESSOA, 2014). Administration of small quantities of fresh leaves of Palicourea aeneofusca (OLIVEIRA et al., 2013) and A. septentrionalis (DUARTE et al., 2014) also induce partial resistance to poisoning by MFA in goats, suggesting that MFAdegrading bacteria may be normal inhabitants of the ruminal flora and that the ingestion of this substrate stimulates their multiplication (CAMBOIM et al., 2012b). Furthermore, it was found that this resistance could be transmitted from resistant animals to susceptible animals by the transfer of ruminal content (DUARTE et al., 2014). These results suggest the need to study different ways of inducing resistance to MFA poisoning under field conditions, including the inoculation of bacteria that degrade MFA and the transfer of rumen contents from resistant animals.

The objective of this study was to determine whether resistance to poisoning by $\boldsymbol{A}$. septentrionalis in goats conferred by the inoculation of the MFA-degrading bacteria $A$. dichloromethanicus and $P$. kullae may be transferred, through the transfer of rumen content, to goats that had never ingested MFA-containing plants.

\section{MATERIAL AND METHODS}

Sixteen young mixed-breed goats (8 females and 8 males) raised in areas free of MFAcontaining plants were randomly divided into two groups of eight animals each: a control group (Group 2) and a group of goats that received rumen contents (Group 1) from two resistant goats. In these two goats, the resistance had previously been induced by daily oral administration for 10 days of a $60 \mathrm{ml}$ solution containing $\boldsymbol{A}$. dichloromethanicus and P. kullae, diluted to 1 on the McFarland scale. After the tenth day of inoculation, the goats started to ingest daily doses of $5 \mathrm{~g} \mathrm{~kg}^{-1}$ body weight of green leaves of $\boldsymbol{A}$. septentrionalis for an 8-day period (PESSOA, 2014).

Rumen content of the resistant goats was obtained in sterile glass bottles, by means of a suction pump connected to a ruminal probe. After being filtered through sterile gauze, $160 \mathrm{ml}$ of rumen juice was administered daily for four days to each Group 1 goat. Daily administration of $5 \mathrm{~g} \mathrm{~kg}^{-1}$ of recently collected, green $\boldsymbol{A}$. septentrionalis leaves was initiated on the 4 th day of the ruminal content transfer. Leaves were administered orally for eight days by placing small amounts into the mouths of the animals. Goats in Group 2 (control) received the plant in the same way as Group 1. The plant provided for the animals was collected in the city of Teixeira (S7 ${ }^{\circ} 12.24^{\prime} \mathrm{O} 37^{\circ} 15.11^{\prime}$, elevation of $749 \mathrm{~m}$ ), located in the state of Paraíba, Brazil, in the same location of the plant utilized by DUARTE et al. (2014).

Each day, before the administration of the plant, the animals were observed and their heart and respiratory rates, ruminal movements and rectal temperatures were measured. After the administration of the plant, the goats were forced to walk for 10 minutes before the aforementioned parameters were measured again. Plant supply was ceased in the goats that showed clinical signs of intoxication (depression, reluctance to walk, muscle tremors, incoordination and sternal recumbency).

Before administering $\boldsymbol{A}$. septentrionalis and every 2 days after the start of its intake, jugular vein blood samples were collected in vacuum tubes without anticoagulant $\left(\right.$ Vacutainer $\left.^{\circledR}\right)$. Serum samples were obtained after centrifugation (Eppendorf ${ }^{\circledR}$ centrifuge, model 5804R) at $1600 \mathrm{G}$ for 15 minutes. The serum activities of aspartate aminotransferase (AST), gamma glutamyltransferase (GGT), alkaline phosphatase (ALP) and the serum concentrations of creatinine, urea, total protein, albumin, globulin, calcium, phosphorus, potassium and sodium were determined using commercial kits $\left(\right.$ Labteste $\left.^{\circledR}\right)$. Readings were performed in a semi-automatic biochemical analyzer (Bioclin Systems II) and the results were interpreted according KANEKO et al. (2008).

Animals that showed no clinical signs characteristic of intoxication throughout the period of administration of the plant were considered resistant. Fischer test was used to compare the number of goats that presented clinical signs between the two groups. The difference in the serum levels of phosphorus and calcium in Groups 1 and 2 and the average amount of plant consumed by these animals were analyzed statistically using the non-parametric Mann-Whitney test because the use of the Shapiro-Wilk test (ZAR, 1999) showed a non-normal distribution of the data. Data analysis was performed using the program $\mathrm{R}$ 3.0.3 with a significance level of $5 \%$.

\section{RESULTS}

The goats in Group 1 ingested the plant for eight days, until the end of the administration period. Only two animals showed initial signs of mild tachycardia and engorgement of the jugular vein after 
exercise on the 4th and 5 th day of the experiment; however, the daily dose of the plant was maintained and, in the following days, these signs were no longer evident. These results were significantly different $(\mathrm{P}=0.00007)$ from those of the control group in which all goats showed clinical signs of intoxication and the administration of the plant was ceased between the 3rd and 7th days (Table 1). The plant dose ingested by the animals in Group 2 (control) $\left(25 \pm 6.54 \mathrm{~g} \mathrm{~kg}^{-1}\right)$ was significantly different $(\mathrm{P}=0.0001)$ than the dose ingested by Group $1\left(40 \mathrm{~g} \mathrm{~kg}^{-1}\right)$, which had received the ruminal contents of resistant animals.

Clinical signs of goats in Group 2 (control) were characterized by tachycardia and tachypnea, followed by engorgement of the jugular vein and positive venous pulse and culminating with depression, reluctance to walk, muscle tremors, incoordination and sternal recumbency. The latency (average number of days) of the initial dose until the first observation of clinical signs in this group was $3.5 \pm 1.06$ days after the average intake of $17.5 \pm 5.34 \mathrm{~g} \mathrm{~kg}^{-1}$ of $A$. septentrionalis. The administration of the plant was suspended after $5 \pm 1.30$ days, with a total average consumption of $25 \pm 6.54 \mathrm{~g} \mathrm{~kg}^{-1}$ at the time of suspension, due to the presentation of overt signs of intoxication with risk of death (Table 1).

All intoxicated animals recovered over a period of 12-24 hours after the cessation of ingestion of the plant, except for one goat that died two days after the onset of the first clinical signs. Pulmonary edema was observed at necropsy. Upon histology, the only significant alteration was vacuolar degeneration and necrosis in the epithelial cells of the distal convoluted tubules of the kidney.

No changes were observed in serum creatinine, urea, total protein, albumin or magnesium concentrations nor in the serum activities of AST, GGT and ALP. After the administration of $\boldsymbol{A}$. septentrionalis serum concentrations of calcium and phosphorus in goats from Group 1 remained within normal ranges (KANEKO et al., 2008). However, in Group 2 (control), serum concentrations of phosphorus were increased and serum concentrations of calcium were decreased, differing significantly from Group $1(\mathrm{P}=0.02)$ (Table 2).

\section{DISCUSSION}

The results presented in this study demonstrate that the transfer of rumen content from goats resistant to poisoning by $\boldsymbol{A}$. septentrionalis to susceptible goats, induces resistance to the poisoning, allowing the consumption of toxic amounts of the plant without causing intoxication. In this case, the resistance of the ruminal fluid donor animals had been acquired by the inoculation of MFA-degrading bacteria followed by the administration of $\boldsymbol{A}$. septentrionalis, which suggests the possibility of using transfaunation of ruminal content as a way to transfer resistance to MFA-containing plants from resistant to susceptible animals.

GREGG et al. (1998) reported the reduction of clinical signs of intoxication by MFA in sheep intraruminally inoculated with the bacterium Butyrivibrio fibrisolvens, genetically modified with a gene derived from a species of Moraxella, encoding a dehalogenase. Studies of our research group reported partial induction of resistance to poisoning by $\boldsymbol{A}$. septentrionalis in six goats after intraruminal inoculation of $\boldsymbol{A}$. dichloromethanicus and $\boldsymbol{P}$. kullae (PESSOA, 2014). Two of these goats were used as donors of rumen contents in this research; they had received the bacteria and subsequently $\boldsymbol{A}$. septentrionalis, presenting mild clinical signs of intoxication after eight days of ingesting daily doses of $5 \mathrm{~g} \mathrm{~kg}^{-1}$ of the same plant used in this experiment. Because all goats that received ruminal contents

Table 1 - Time of intake and amount of Amorimia septentrionalis ingested by the control group (Group 2).

\begin{tabular}{|c|c|c|c|c|}
\hline \multirow[t]{2}{*}{ Goat n. } & \multicolumn{2}{|c|}{ 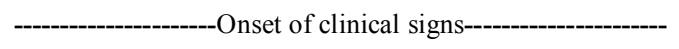 } & \multicolumn{2}{|c|}{ 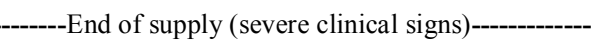 } \\
\hline & Days & Amount of plant consumed $\left(\mathrm{g} \mathrm{kg}^{-1}\right)$ & Days & Amount of plant consumed $\left(\mathrm{g} \mathrm{kg}^{-1}\right)$ \\
\hline 1 & 3 & 15 & 4 & 20 \\
\hline 2 & 4 & 20 & 5 & 25 \\
\hline 3 & 5 & 25 & 7 & 35 \\
\hline 4 & 3 & 15 & 5 & 25 \\
\hline 5 & 5 & 25 & 6 & 30 \\
\hline 6 & 3 & 15 & 6 & 30 \\
\hline 7 & 2 & 10 & 3 & 15 \\
\hline 8 & 3 & 15 & 4 & 20 \\
\hline $\bar{x}_{ \pm \sigma *}$ & $3.5 \pm 1.06$ & $17.5 \pm 5.34$ & $5 \pm 1.3$ & $25 \pm 6.54$ \\
\hline
\end{tabular}

${ }^{*}$ Mean \pm standard deviation. 
Table 2 - Mean values and standard deviations of serum calcium and phosphorus of 16 goats belonging to Groups 1 and 2 of the experiment, submitted to the administration of Amorimia septentrionalis orally for 8 days.

\begin{tabular}{|c|c|c|c|}
\hline & Time (Days) & Group 1 & Group 2 \\
\hline \multirow{5}{*}{$\begin{array}{l}\text { Phosphorus } \\
\left(\mathrm{g} \mathrm{ml}^{-1}\right)\end{array}$} & 0 & $6.42 \pm 0.77$ & $6.38 \pm 1.00$ \\
\hline & 2 & $6.46 \pm 1.21$ & $9.12 \pm 1.93$ \\
\hline & 4 & $7.47 \pm 1.79$ & $9.70 \pm 3.03$ \\
\hline & 6 & $7.53 \pm 1.61$ & $11.06 \pm 2.86$ \\
\hline & 8 & $7.55 \pm 1.19$ & $11.08 \pm 2.28$ \\
\hline \multirow{5}{*}{$\begin{array}{l}\text { Calcium } \\
\left(\mathrm{g} \mathrm{ml}^{-1}\right)\end{array}$} & 0 & $8.94 \pm 0.67$ & $8.96 \pm 1.00$ \\
\hline & 2 & $8.92 \pm 0.65$ & $8.28 \pm 1.63$ \\
\hline & 4 & $9.05 \pm 0.30$ & $7.08 \pm 1.72$ \\
\hline & 6 & $9.35 \pm 0.50$ & $7.83 \pm 3.06$ \\
\hline & 8 & $8.97 \pm 0.86$ & $8.50 \pm 2.95$ \\
\hline
\end{tabular}

Reference values (calcium: $8.9-11.77 \mathrm{~g} \mathrm{ml}^{-1}$; phosphorus: $4.2-9.1 \mathrm{~g} \mathrm{ml}^{-1}$ ). From day 2 to day 8 serum concentrations of Ca and $\mathrm{P}$ in $\mathrm{Group} 2$ (control) were statistically different from group $1(\mathrm{P}=0.02)$ by Mann-Whitney test.

in the present research also ingested $5 \mathrm{~g} \mathrm{~kg}^{-1}$ of $\boldsymbol{A}$. septentrionalis daily for eight days without showing clinical signs, it can be inferred that the transfer of rumen content from resistant goats confers similar resistance to that acquired by the intraruminal inoculation of MFA-degrading bacteria followed by the plant administration during the challenge. DUARTE et al. (2014) found that the transfer of ruminal content from animals fed non-lethal doses of the plant for extended periods also confers partial resistance to intoxication.

These results, taken together, suggest that the three techniques (inoculation of bacteria that degrade MFA, administration of plants containing MFA and transfer of ruminal contents) may be used alone or in combination to induce resistance to poisoning. Further research should be performed to establish the degree and duration of the induced resistance. One factor is that the resistance induced by these techniques depends on the amount and the toxicity of the plant that the animals eat spontaneously: small doses may improve resistance, but larger doses may surpass the resistance, causing poisoning. SILVA et al. (2008) reported that animals raised in areas where $\boldsymbol{A}$. septentrionalis occurs are less susceptible to the poisoning than animals raised in areas where this plant does not exist. However, it is unknown whether this resistance is acquired by the ingestion of non-toxic doses of the plant or due to natural selection because of the death of the susceptible animals. Resistance in animals that remain in areas where the plant occurs have not been described in poisoning by the Palicourea species, which are more toxic than Amorimia spp. (TOKARNIA et al., 2012; LEE et al., 2012). Thus, it is expected greater difficulty in inducing resistance to poisoning by Palicourea spp. than to poisoning by Amorimia spp.
The decrease of serum calcium and the increase of serum phosphorus observed in the poisoned goats were also observed by PEREIRA et al. (1996) and BORBOLETA et al. (2011), who suggested that the changes in the homeostasis of these elements is due to the action of the MFA. According to BORBOLETA et al. (2011), the disturbances in these electrolytes may destabilize the resting potential of cell membranes affecting several metabolic pathways dependent on these ions. In the Krebs cycle, the MFA present in $\boldsymbol{A}$. septentrionalis is transformed into fluorocitrate, and during this process, there is a drop in ATP production, which leads to blocking a series of energy-dependent metabolic processes (CLARKE, 1991) that can destabilize calcium and phosphorus homeostasis. The clinical signs exhibited by animals of Group 2 and the vacuolation of epithelial cells of distal convoluted tubules of the kidneys observed in the single animal that died are similar to those described previously in ruminants poisoned by MFA-containing plants (MEDEIROS et al., 2002; RIET-CORREA et al., 2006; SILVA et al. 2008; VASCONCELOS et al, 2008; TOKARNIA et al., 2012; DUARTE et al., 2014).

\section{CONCLUSION}

The transfer of ruminal fluid from goats previously inoculated with MFA-degrading bacteria to susceptible goats induces resistance to poisoning by $A$. septentrionalis.

\section{ACKNOWLEDGMENTS}

This research was supported by the National Institute for Science and Technology for the Control of Plant Poisonings. 
Conselho Nacional de Desenvolvimento Científico e Tecnológico (CNPq), grant 573534/2008-0.

\section{ETHICAL COMMITTEE}

The experiment was approved by the UFCG Ethical Committee on animal experimentation, process CEP 69-2013.

\section{REFERENCES}

BORBOLETA, L.R. et al. Perfil bioquímico sanguíneo na intoxicação experimental com extrato de Mascagnia rigida (A. Juss.) Griseb. (Malpighiaceae) em coelhos. Arquivo Brasileiro de Medina Veterinária e Zootecnia, v.63, n.5, p.1113-1123, 2011. Available from: <http://www.scielo.br/scielo.php?pid=S010209352011000500011\&script $=$ sci_arttext $>$. Accessed: Jun. 19, 2014. doi: $10.1590 / \mathrm{S} 0102-09352011000500011$.

CAMBOIM, E.K.A. et al. Isolation of sodium fluoroacetate degrading bacteria from caprine rumen in Brazil 2012a. Scientific World Journal, v.2012, ID 178254, p.6. Available from: <http:/ www.ncbi.nlm.nih.gov/pmc/articles/PMC3417187/>. Accessed: Jul. 17, 2013. doi: 10.1100/2012/178254.

CAMBOIM, E.K.A. et al. Defluorination of sodium fluoroacetate by bacteria from soil and plants in Brazil 2012b. Scientific World Journal, v.2012, id.149893, p.5. Available from: <http://www. ncbi.nlm.nih.gov/pmc/articles/PMC3349100/>. Accessed: Mar. 03, 2013. doi: $10.1100 / 2012 / 149893$.

CLARKE D.D. Fluoroacetate and fluorocitrate: mechanism of action. Neurochemical. Research, v.16, n.9, p.1055-1058, 1991.

DUARTE, A.L.L. et al. Induction and transfer of resistance to poisoning by Amorimia (Mascagnia) septentrionalis in goats. Journal of Applied Toxicology, v.34, n.2, p.220-223, 2014. Available from: $<$ http://www.ncbi.nlm.nih.gov/pubmed/23400835>. Accessed: Mar. 03, 2013. doi: 10.1002/jat.2860.

GREGG, K. et al. Genetically modified ruminal bacteria protect sheep from fluoracetate poisoning. Applied and Environmental Microbiology, v.64, n.9, p.3496-3498, 1998. Available from: $<$ http://aem.asm.org/content/64/9/3496.full $>$. Accessed: Jun. 12, 2014. doi: 10.1128/AEM.02188-14.

KANEKO, J.J. et al. Blood analyte reference values in some laboratory animals. In: Elsevier. Clinical biochemistry of domestic animal. 5.ed. Philadelphia: Academic, 2008. Appendix IX, p.881-887.

LEE, S.T. et al. Detection of monofluoroacetate in Palicourea and Amorimia species. Toxicon, v.60, n.5, p.791-796, 2012. Available from: $<$ http://www.sciencedirect.com/science/article/pii/ S0041010112005065>. Accessed: Jun. 12, 2014. doi: 10.1016/j. toxicon.2012.05.029

MAMEDE, M.C.H. Amorimia in Lista de Espécies da Flora do Brasil. Jardim Botânico do Rio de Janeiro, 2010. Online. Available from: <http://floradobrasil.jbrj.gov.br/2010/FB101439>. Accessed: Sept. 20, 2012.

MEDEIROS, R.M.T. et al. Sudden bovine death from Mascagnia rigida in Northeastern Brazil. Veterinary and Human Toxicoly, v.44, n.5, p.286-288, 2002. Available from: <http://www.ncbi. nlm.nih.gov/pubmed/12361113>. Accessed: Jun. 05, 2013. doi: 10.1590/S0100-736X2008001000003.

OLIVEIRA, A.C. et al. Intoxicação por um "tíngui” (Mascagnia rígida Griseb.) em caprinos na Bahia. In: CONGRESSO BRASILEIRO DE MEDICINA VETERINÁRIA, 16., 1978, Salvador, Bahia. Anais... Bahia: CFMV, 1978. V.1, p.172.

OLIVEIRA, M.D. et al. Indução de resistência à intoxicação por Palicourea aeneofusca (Rubiaceae) mediante administração de doses sucessivas não tóxicas. Pesquisa Veterinária Brasileira, v.33, n.6, p.731-734. 2013. Available from: <http://www. scielo.br/scielo.php?pid=S0100736X2013000600007\&script $=$ sci_arttext $>$. Accessed: Mar. 06, 2014. doi: 10.1590/S0100$736 \bar{X} 2013000600007$

PEREIRA,A.S. et al. Alterações bioquímicas e patológicas em caprinos intoxicados por "tinguí" (Mascagniarigida). In: CONGRESSO PANAMERICANO DE CIÊNCIAS VETERINÁRIAS, 15., 1996, Campo Grande, MS. Anais... Campo Grande: Associação Panamericana de Ciências Veterinárias, 1996. V.1, p.152.

PESSOA C.R.M. et al. Importância econômica, epidemiologia e controle das intoxicações por plantas no Brasil. Pesquisa Veterinária Brasileira. v.33, n.6, p.752-758, 2013. Available from: $\quad<$ http://www.scielo.br/scielo.php?script=sci arttext\&pid $=\mathrm{S} 0100736 \mathrm{X} 2013000600011>$. Accessed: Jan. 13, 2014 . doi: 10.1590/S0100-736X2013000600011

PESSOA, D.A.N. Resistência à intoxicação por Amorimia septentrionalis em caprinos, induzida pela inoculação ruminal das bactérias Pigmentiphaga kullae e Ancylobacter dichloromethanicus. Pesquisa Veterinária Brasileira. v.35, n.2, p.115-128, 2015. Available from: <http://www.pvb.com.br/ pdf artigos/23-04-2015 16-04Vet\%201851 3878\%20LD.pdf>. Accessed: Apr. 13, 2015. $\overline{\text { doi: }}$ 10.1590/S0100-736X2013000600011.

RIET-CORREA, F. et al. Plantas tóxicas da Paraíba. Patos: Centro de Saúde e de Tecnologia Rural/SEBRAE/PB, 2006. p.1-58.

SILVA, I.P. et al. Intoxicação natural pelas folhas de Mascagnia rígida (Malpighiaceae) em ovinos. Arquivos do Instituto Biológico, v.75, n.2, p.229-233, 2008. Available from: <http:// www.biologico.sp.gov.br/docs/arq/v75 2/silva.pdf $>$. Accessed: Mar. 10, 2014. doi: 10.1590/S1808-16572013000300001.

TOKARNIA, C.H. et al. Plantas tóxicas do Brasil para animais de produção. 2.ed. Rio de Janeiro: Helianthus, 2012. 566p.

TOKARNIA, C.H. et al. Aspectos clínicopatológicos complementares da intoxicação por algumas plantas tóxicas brasileiras. Pesquisa Veterinária Brasileira, v.14, n.4, p.111-121, 1994. Available from: $<$ http://www.scielo.br/scielo.php?script $=$ sci arttext\&pid $=$ S0100-736X1998000100003>. Accessed: Apr. 03, 2014. doi: 10.1590/S0100-736X1998000100003.

VASCONCELOS, J.S. et al. Intoxicação por Mascagnia rígida (Malpighiaceae) em ovinos e caprinos. Pesquisa Veterinária Brasileira, v.28, n.10, p.521-526, 2008. Available from: <http:// www.scielo.br/pdf/pvb/v28n10/v28n10a13.pdf >. Accessed: Feb. 03, 2014. doi: 10.1590/S0100- 736X2008001000013.

ZAR, J.H. Biostatistical analysis. 4.ed. New Jersey: Prentice Hall, 1999. 929p. 